\title{
CHEMICAL COMPOSITION OF SEA BUCKTHORN LEAVES, BRANCHES AND BARK
}

\author{
Ina Gradt\#, Sascha Kühn, J.-Thomas Mörsel, and Galina Zvaigzne \\ Untersuchungs-, Beratungs- \& Forschungslaboratorium GmbH, An der Mühle 1, 15345 Altlandsberg, GERMANY \\ \# Corresponding author, ina.gradt@ubf-research.com
}

Communicated by Dalija Seglina

\begin{abstract}
Sea buckthorn leaves and branches presently create waste-/by-products of harvesting after pruning the plants. It is already known that sea buckthorn berries are important for their chemical composition and based on this occupy a wide field in nutrition. We raised the idea that sea buckthorn leaves, branches, and especially the bark, have also an extraordinary chemical composition like the berries. The aim of this study was to describe these by-products. For this purpose, detailed full analyses of corresponding samples from Russia (seven varieties) and Germany (four varieties) were performed. Especially the dry mass, fat content, proteins, carbohydrates, starch content, and crude fiber were investigated to obtain an overview. Minor components like total phenol content, metals, and water- and fat-soluble vitamins were also studied. All analytical parameters were based on an official collection of analysis methods (German ASU - amtliche Sammlung von Untersuchungsverfahren). The results of the full analysis of leaves and branches show some interesting aspects about the differences between male and female plants. Furthermore, we observed differences between Russian and German sea buckthorn varieties. Investigation of minor components showed that vitamins were present in very low amount $(<0.1 \%)$.

Key words: sea buckthorn, sea buckthorn leaves, sea buckthorn branches, chemical, composition, economical use.
\end{abstract}

\section{INTRODUCTION}

This study was a cooperation project between two German companies, UBF GmbH and NIG - Nahrungsingenieurtechnik GmbH (Magdeburg), and two Russian institutes, NIIL - Institute for Horticulture of Siberia M.A. Lisavenko (Barnaul), Russian Academy of Agricultural Science, and Institute for Cytology and Genetics (Novosibirsk), Russian Academy of Science. The interest of the initiator, UBF $\mathrm{GmbH}$, and the cooperation partner was to obtain an overview about the chemical composition of sea buckthorn leaves and 1-2- year old branches, especially the bark.

It is already known that sea buckthorn represents a robust, unpretentious plant which can adapt to all extreme environmental conditions. There exist a variety of species of sea buckthorn that differ in their specific characteristics (growth height, maturity, berry size, etc.). In the past and presently the berry of the sea buckthorn plant stands in focus. Sea buckthorn, and especially its berries, contain have a big variety of health promoting ingredients, e.g., carotinoids, flavonoids, and ascorbic acid (vitamin C) and because of these resources sea buckthorn is regarded as an "allrounder". Not only the food industry benefits from the SBT berry (in form of juice, oil or liqueur) also the cosmetic industry (skin cream) and pharmaceutical companies (Beveridge et al., 1999; Eidelant, 2003). Nowadays the sea buckthorn berry is very well known with all its advantages and disadvantages concerning the health benefits and nutrition aspects.

The focus of this study was plant material from sea buckthorn (SBT) that remained as biomass of leaves and branches after cutting of fruit-bearing branches (Dwidvedi, 2006) and after pruning. This plant material is considered as waste produced during harvest, but possibly represents a new valuable raw material. In general the agriculture industry is interested in new findings about the use of the waste-/by-products and the resulting economically aspects. The aim of the present study was to describe sea buckthorn residue in terms of new profitable commodities.

Few studies have focused on the chemical properties of byproducts from sea buckthorn harvest (leaves and branches) (Brad, 2007; Maheshwari, 2011; Mishra, 2011). This residue potentially contains interesting chemical compounds like antioxidant compounds e.g. flavonoids and carotenes, and also oil containing large amounts of unsaturated fatty acids.

The aim of this work is to determine chemical composition of sea buckthorn varieties from Russia and German as well 
as among male and female sea buckthorn plants from Russia among themselves. The evaluated results will show whether the SBT leaves, SBT branches and bark represent potential economically use.

\section{MATERIALS AND METHODS}

As raw material seven Russian varieties ('Alej', 'Gnom', 'Inja', 'Tschetschek', 'Claudia', 'Elisabetha', and 'Altajskaja') and four German varieties ('Askola', 'Leikora', 'Hergo', and 'Habego') were collected. The sampled material from harvesting (2015) was frozen immediately ( $\mathrm{T}=$ $\left.-20{ }^{\circ} \mathrm{C}\right)$. To obtain bark samples, the branches were easily peeled. The full analysis of samples included determination of the dry mass, fat content, proteins, carbohydrates/sugar, starch content and crude fibre. In addition to this, minor components like fat- and water-soluble vitamins, metals and polyphenolic compounds were determined.

Standard laboratory methods were performed for the analysis of the samples.

The determination of dry mass was based on the ASU method 22.02/04-4 2010-09 (Anonymous, 1975; 2010). Crude fibre determination was determined based on a method described by K. Scharrer and K. Kürschner (Rauscher et al., 1986; Anonymous, 2005e). Fat extraction by soxhlett was based on ASU method 06.00-6 1980-09; 13.05-3 2002-05 and 17.00-4 1982-05 (Anonymous, 1975; 2005e; 2010). Protein concentration was determined by Kjeldahl method (ASU 06.00-7 2007-04 and 17.00-15 1988-12) (Anonymous, 2005e). The concentration of carbohydrates was carried out according to ASU 39.00-6 1981 and 31.00-11 1984-11(Anonymous, 2005e). This method is based on the process by Luff/Schoorl which determines carbohydrate concentration after inversion. The determination of starch was carried out by polarimetric method (ASU norm 17.00-5 2003-12) (Anonymous, 2005).

The total phenol concentration was determined by colour reaction of phosphomolybdate with the present polyphenolic compounds in strong alkaline solution containing Folin-Ciocalteu-reagent. The calculation of the polyphenol concentration was carried by calibration with gallic acid (Anonymous, 2005).

Metals ( $\mathrm{Cu}, \mathrm{Ni}, \mathrm{Mn}, \mathrm{Cr}, \mathrm{Fe}, \mathrm{Sr}, \mathrm{Zn}$ and total phosphorus) were determined in acid digestion by AAS (atomic absorption spectrometry) (Anonymous, 2005).

The analysis of water soluble vitamins riboflavin, niacin and pyridoxine was determined by HPLC - analysis with the following conditions: column: RP 18, $250 \times 4$; eluent $=$ acetonitrile/ water/ acetic acid (15:85:1); flow $=1.2 \mathrm{~mL} /$ min; UV - detection, $\lambda=254 \mathrm{~nm}$.

Vitamin E concentration was also analysed by HPLC. For the isolation of vitamin $\mathrm{E}$ the samples were prepared as follows (Anonymous, 2005):
1) Saponification with ethanolic $\mathrm{KOH}$ and $50 \mathrm{~mL}$ solvent mixture $\left(\mathrm{t}=1 \mathrm{~h} ; \mathrm{T}=80{ }^{\circ} \mathrm{C}\right)$.

2) After cooling down, the solution was shaken three times with $50 \mathrm{~mL}$ petroleumether.

3) Petroleum phases were combined and washed with water (until neutral reaction).

4) Samples were dried with $\mathrm{Na}_{2} \mathrm{SO}_{4}$.

5) Petroleumether was evaporated.

6) The recovered vitamin $\mathrm{E}$ was dissolved in $10 \mathrm{~mL}$ iso-octan and injected into a HPLC-system (column: NP LiChrosrb Si 60; eluent = isooctane/ ethyl acetate (96:4); flow $=1 \mathrm{~mL} / \mathrm{min}$; UV - detection, $\lambda=295 \mathrm{~nm}$ ).

All results entered in Microsoft ${ }^{\circledR}$ Office Excel 2003 (11.8404.8405) SP3, copyright (C) 1985-2003 Microsoft Corporation and all calculations made with this software system (average, standard deviation, percentage share etc.).

\section{RESULTS}

The following graphs summarise the chemical analyses of sea buckthorn leaves and branches from Russia.

Figure 1 presents the dry mass of sea buckthorn leaves and branches. The dry mass of sea buckthorn branches from Russia varied from $53.42 \%$ to $62.09 \%$ (average 56.2\%) and the dry mass of the sea buckthorn leaves from Russia varied from $35.15 \%$ to $43.13 \%$ (average $39.90 \%$ ).

The following data was obtained from the dry mass of sea buckthorn leaves and branches from Russia.

Figure 2 shows the results of crude fibre analysis.

The crude fibre concentration of female sea buckthorn branches is up to $6 \%$ higher than that of the male. Crude fibre concentration of sea buckthorn leaves was similar, except for higher amounts $(26.28 \%)$ in variety 'Alej'.

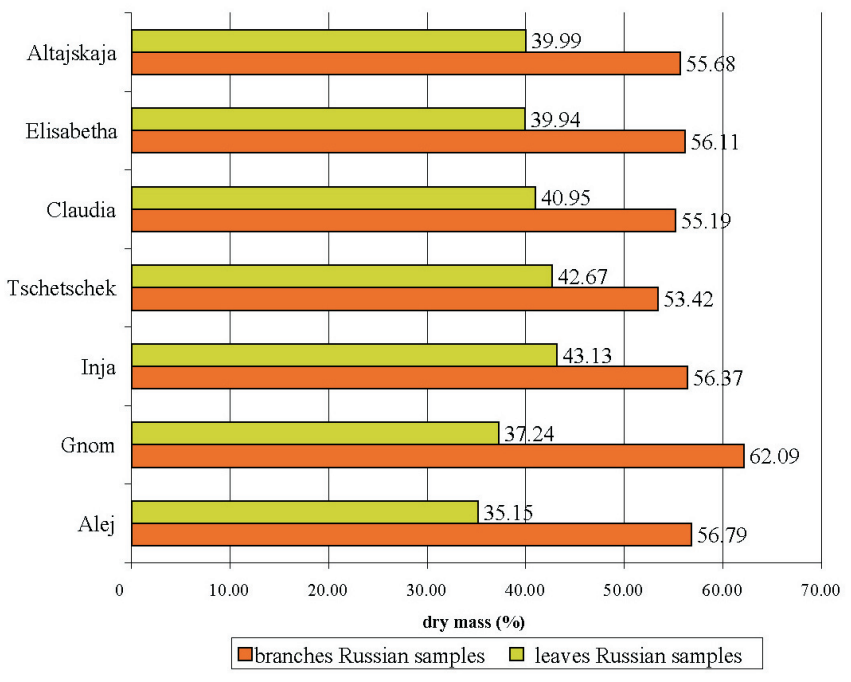

Fig. 1. Dry mass (\%) of sea buckthorn leaves and branches from Russia. 


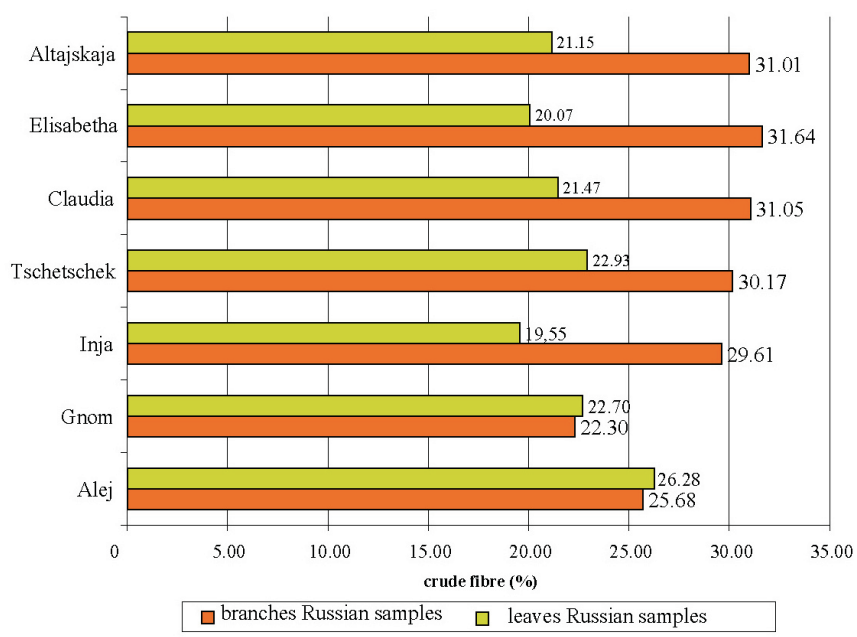

Fig. 2. Crude fibre (\%) of sea buckthorn leaves and branches from Russia.

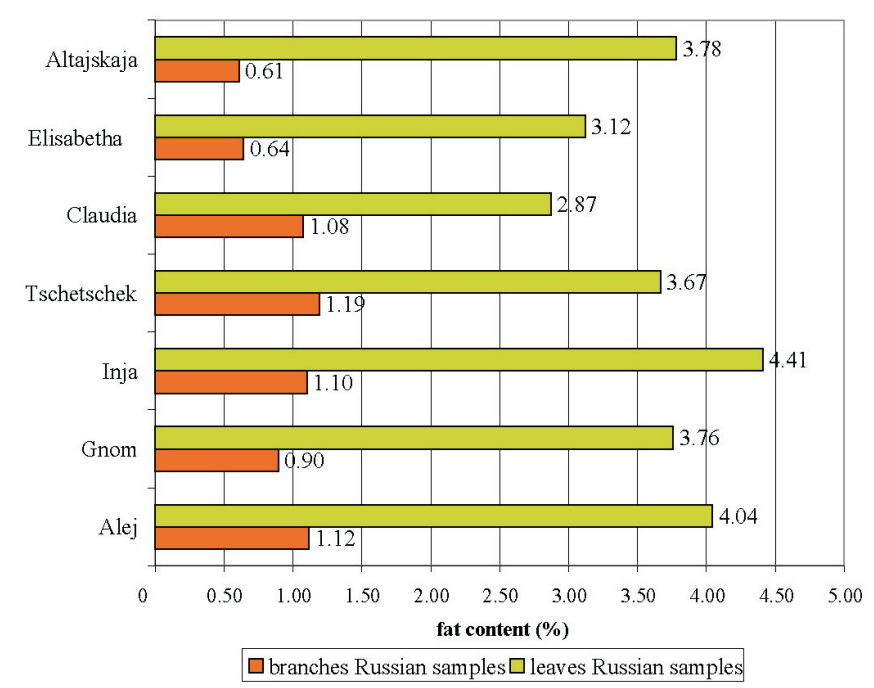

Fig. 3. Fat concentration (\%) of sea buckthorn leaves and branches from Russia.

Fat concentration of SBT leaves and branches from Russia did not much differ between male and female plants (Fig. 3 ). The leaves had much higher fat concentration than that of branches due to different cell structures of the fresh/green leaves and lignified branches. On average the SBT leaves and branches from Russia contained $3.66 \%$ and $0.95 \%$ fat, respectively. The varieties 'Elisabetha' and 'Altajskaja' had the lowest fat concentration $(0.6 \%)$.

Figure 4 shows the results of protein analysis. Female and male SBT plants did not significantly differ in protein concentration, but it was higher in leaves than in branches. The protein concentration in leaves ranged from $20.97 \%$ to $24.03 \%$ and in branches from $9.04 \%$ to $12.65 \%$.

The carbohydrate concentration of the SBT leaves and branches from Russia (Fig. 5) did not significantly differ between male and female and ranged from $4.14 \%$ to $8.06 \%$ in leaves from $3.15 \%$ to $4.66 \%$ in branches.

Starch concentration of the SBT varieties from Russia (Fig. 6) did not significantly differ between male and female

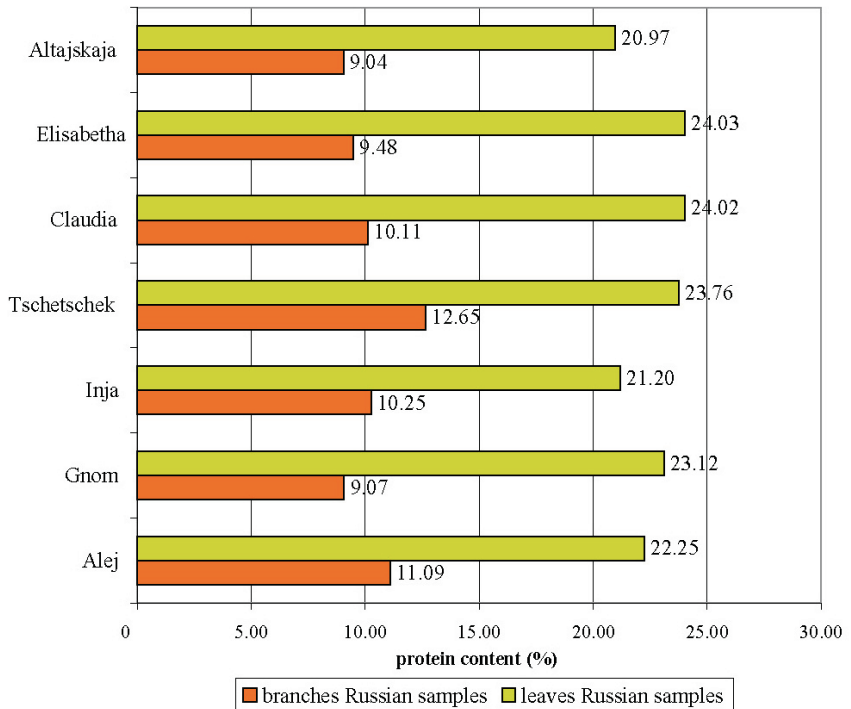

Fig. 4. Protein concentration (\%) of sea buckthorn leaves and branches from Russia.

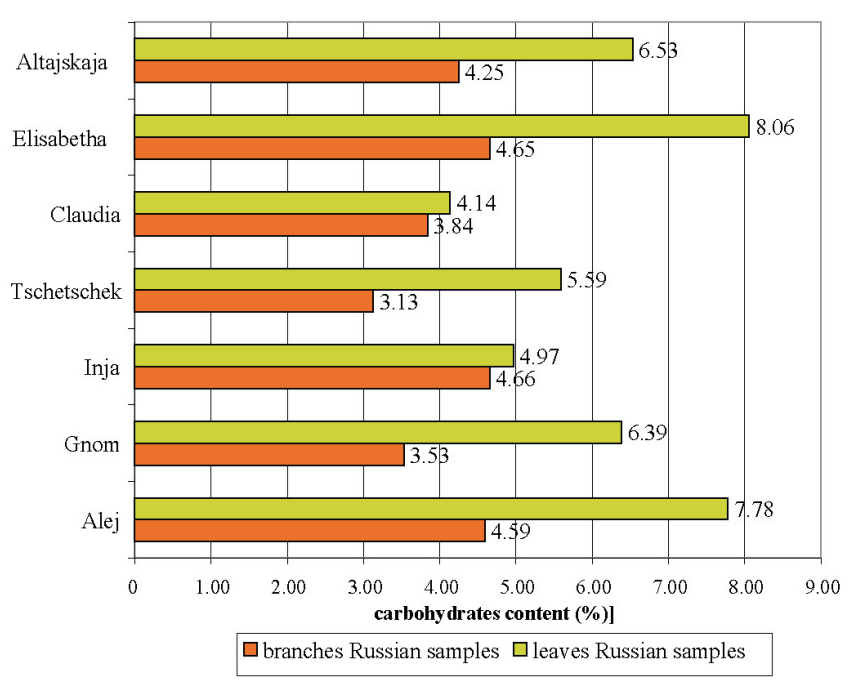

Fig. 5. Carbohydrate concentration (\%) of sea buckthorn leaves and branches from Russia.

plants, but branches of female plants had a higher starch concentration than their leaves. The variety 'Tschetschek' had large variation in starch concentration. In contrast leaves of male plants had higher starch concentration than their branches. The starch concentration of female SBT branches ranged from 7.59 to $12.59 \%$, and of male branches from $7.03 \%$ to $14.56 \%$.

Vitamin E concentration as fat-soluble vitamin and water-soluble vitamins riboflavin, niacin and pyridoxine concentration of sea buckthorn leaves and branches from Russia were also determined (Table 1).

Fat-soluble vitamin E concentration was very low and in branches below $0.1 \%$. Water soluble vitamin concentration was in general variety-specific and $<0.1 \%$.

Metal concentration differed between Russian and German SBT samples (Table 2). We have no information on soil 


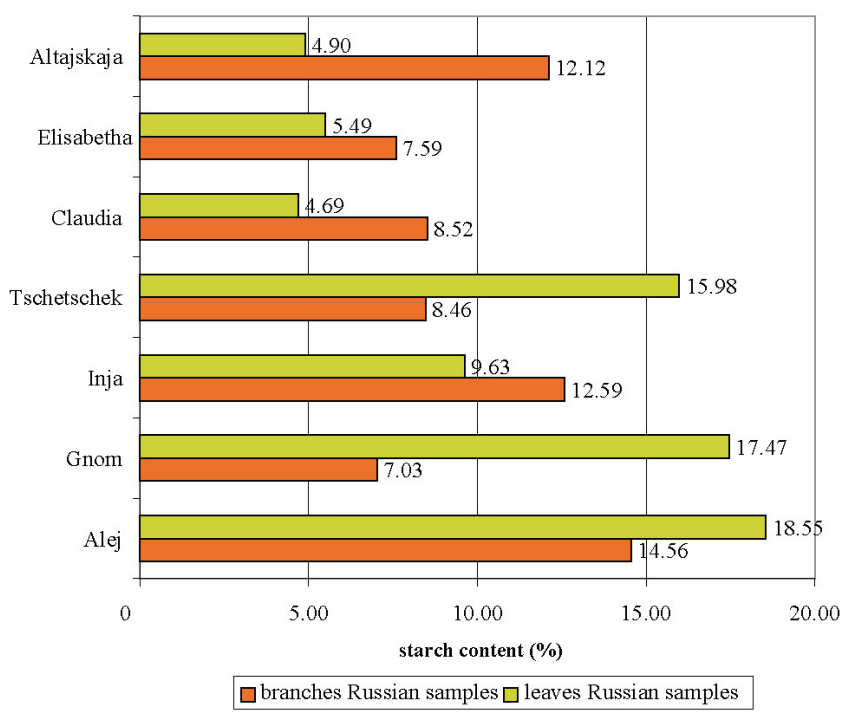

Fig. 6. Starch concentration (\%) of sea buckthorn leaves and branches from Russia.

Table 1

VITAMIN CONCENTRATIONS OF SBT LEAVES (GREEN) AND BRANCHES (GREY) FROM RUSSIA

\begin{tabular}{lcccccc}
\hline \multicolumn{1}{c|}{ Samples } & $\begin{array}{c}\text { niacin } \\
\mathrm{mg} / 100 \mathrm{~g}\end{array}$ & $\begin{array}{c}\text { pyridoxine } \\
\mathrm{mg} / 100 \mathrm{~g}\end{array}$ & $\begin{array}{c}\text { vitamin E } \\
\mathrm{mg} / 100 \mathrm{~g}\end{array}$ & $\begin{array}{c}\text { riboflavin } \\
\mathrm{mg} / 100 \mathrm{~g}\end{array}$ & $\begin{array}{c}\text { niacin } \\
\mathrm{mg} / 100 \mathrm{~g}\end{array}$ \\
\hline Alej & 42.10 & 80.95 & 10.65 & 227.58 & 25.78 \\
Gnom & 45.67 & 72.47 & 9.01 & 287.54 & 24.75 \\
Inja & 42.31 & 61.09 & 11.21 & 232.21 & 23.25 \\
Tschetschek & 37.30 & 45.98 & 13.34 & 1.27 & 35.77 \\
Claudia & 38.28 & 53.05 & 17.89 & 2.26 & 40.21 \\
Elisabetha & 30.98 & 49.19 & 25.71 & 3.73 & 46.08 \\
Altajskaja & 35.61 & 32.64 & 21.29 & 6.91 & 102.80
\end{tabular}

Table 2

SELECTED METAL CONCENTRATIONS (mg/kg) IN SBT LEAVES AND BRANCHES FROM RUSSIA AND GERMANY, HARVESTED IN SEPTEMBER, APRIL, JULY

\begin{tabular}{l|c|c|c}
\hline & Russian & \multicolumn{2}{c}{ German } \\
\hline \multicolumn{1}{c|}{ Element } & September & April & July \\
\hline $\mathrm{Cr}$ & 1.18 & 0.94 & 0.38 \\
$\mathrm{Mn}$ & 52.01 & 944 & 5.16 \\
$\mathrm{Fe}$ & 42.30 & 36.33 & 9.64 \\
$\mathrm{Cu}$ & 4.51 & 4.59 & 2.29 \\
$\mathrm{Zn}$ & 9.84 & 19.10 & 5.05 \\
$\mathrm{Ni}$ & 2.13 & 0.99 & 0.24 \\
$\mathrm{Sr}$ & 59.25 & 12.30 & 3.64 \\
Total phosphorus & 1232.08 & 343.41 & 227.98
\end{tabular}

texture in the sampling sites, but only metal concentrations in leaves, branches, and bark from the Russia and Germany varieties.

Russian leaf samples were harvested in September 2015, while the German samples were harvested in April and July 2015 and consisted mostly of bark.

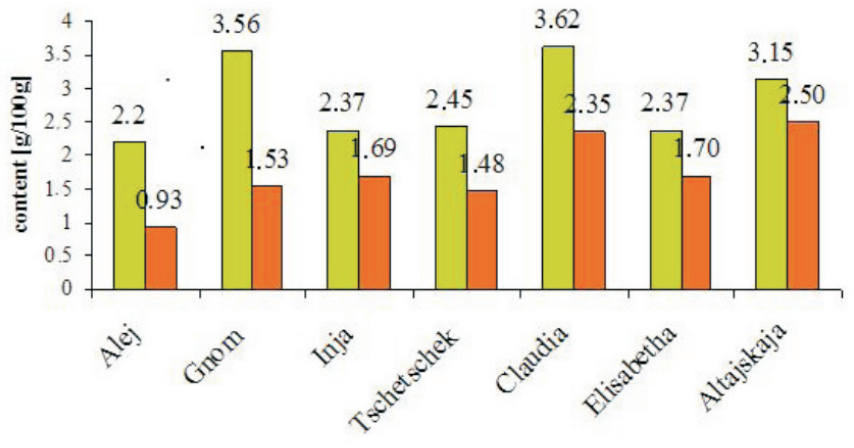

$\square$ polyphenolic compound - leaves $\square$ polyphenolic content - branches

Fig. 7. Total phenol concentration ( $\mathrm{g} / 100 \mathrm{~g})$ of SBT leaves and branches from Russia.

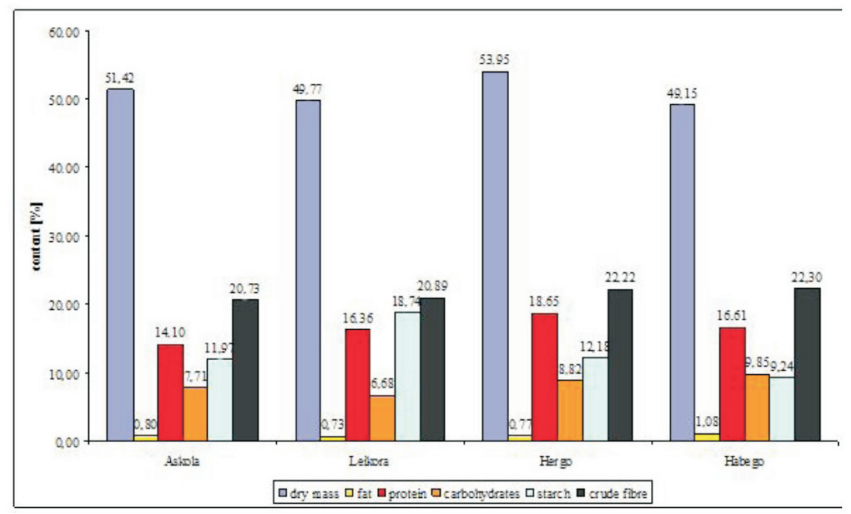

Fig. 8. Chemical composition of SBT bark from German samples.

Figure 7 shows (all poly phenolic compounds) of Russian SBT samples. These components are very total phenol concentration interesting for research because of their antioxidant activity. In general, there are no significant differences in total phenol concentration between male and female SBT plants ( 2.20 to $3.62 \mathrm{~g} / 100 \mathrm{~g}$ ). The total phenol concentration of SBT branches from Russia varied from 0.93 to $2.50 \mathrm{~g} / 100 \mathrm{~g}$. Larger concentration occurred in bark.

The results of chemical analyses from German samples, where in particular bark was analysed, are shown in Figure 8 for varieties 'Askola', 'Leikora', 'Hergo', and 'Habego'.

There were no significant differences in the studied chemical parameters between the German varieties. The dry mass of bark is on average $51.05 \%$. The crude fibre concentration of the four German SBT varieties showed no significant differences (in average $21.53 \%$ ). The carbohydrate concentration varied from 6.68 to $9.85 \%$ and the starch concentration was higher than carbohydrate concentration (9.24 to $18.74 \%$ ), except for 'Habego'. The fat concentration of the German SBT samples was near $1 \%$. The protein concentration in the bark ranged from $14.10 \%$ to $18.65 \%$.

Figure 9 shows determined total phenol concentration of German SBT samples.

The bark harvested in April had much lower phenol concentration $(0.70 \mathrm{~g} / 100 \mathrm{~g})$ than the bark from July $(2.81 \mathrm{~g} / 100$ 
polyphenolic content - German samples

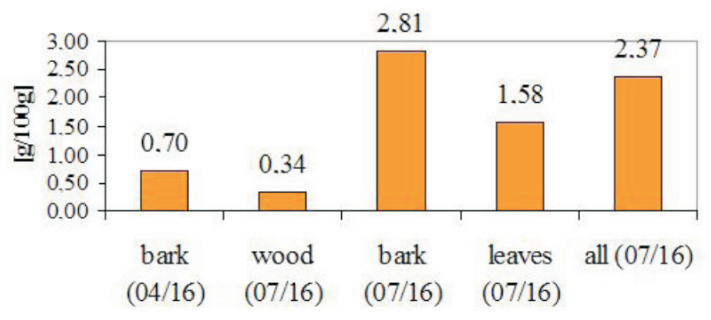

$\square$ polyphenolic content - German samples

Fig. 9. Total phenol of German SBT sample material.

g). The SBT leaves had phenol concentration of about $1.58 \mathrm{~g} / 100 \mathrm{~g}$, which was higher than in wood but lower than in bark harvested in July. Bark had higher phenolic compound concentration and the concentration in combined samples of leaves, bark and wood was lower (2.37 g/100 g) than in bark.

Figure 10 shows a summary of obtained results on chemical composition of sea buckthorn.

\section{DISCUSSION}

Chemical analysis of SBT samples from Russia. Sea buckthorn branches from Russia have in general a higher dry mass than the leaves from Russia, which is not surprising (Fig. 1). However, it is interesting that the leaves of male plants have a lower dry mass than that of females. In contrast, the male branches have a higher dry mass than that of females. Thus, it is clear that male sea buckthorn leaves have a higher water content than that of the females. It is well known that water is very important for the mass transport in plants and that it is stored in cells, particularly in vacuoles. It is possible that female sea buckthorn plants store less water in their leaves because they need it primarily for the berries, which are not present in male sea buckthorn plants.

Crude fibre concentration also differed between the male and female sea buckthorn plants. Female sea buckthorn branches had higher crude fibre concentration than in leaves, but male sea buckthorn plants showed the opposite trend. Also, while there was a significant difference between crude fibre concentration of sea buckthorn leaves and branches in female plants, there was no significant difference for the male plants. In the female sea buckthorn plants from Russia, most of the polysaccharides like cellulose, hemicelluloses and lignin are located in branches in the form of storage materials, but this differentiation does not exist in the male plants, which show approximately equal distribution of polysaccharides in leaves and branches.

Fat concentration of SBT branches and leaves from Russia did not significantly differ between male and female plants (Fig. 3). However, leaves had much higher fat concentration than the branches, which can be explained by the different cell structures of fresh/green SBT leaves and lignified branches. In the future it would be very interesting to deter-

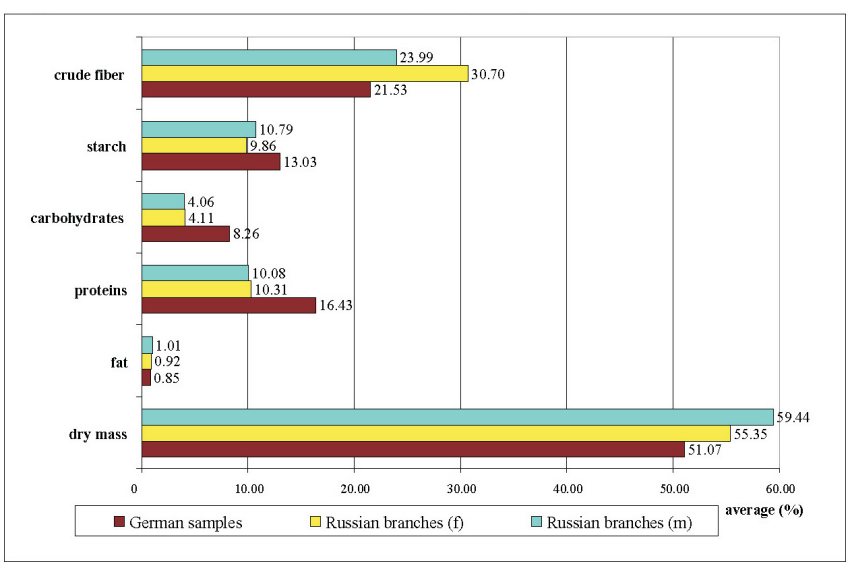

Fig. 10. Comparison of chemical parameters between SBT branches from male and female plants from Russia and SBT bark from German varieties.

mine the fatty acid composition, as there might exist specific unsaturated fatty acids inside the fat that could be useful in the economy for example as an ingredient for cosmetics or dietary supplements.

Carbohydrate concentrations were much higher in SBT leaves than in branches, which is not surprising as leaves produce more carbohydrates in photosynthesis. The produced saccharides are very important for cell structure and serve as an energy source for plants.

Starch concentration on SBT leaves of male plants contained nearly twice as much starch (up to $18.55 \%$ ) than in branches. This difference was not observed in female plants, possibly since energy in the form of carbohydrates is utilised in fruit production. The investigated samples were obtained at harvest in 2015 during September/November, at a time when male plants were able to store starch in leaves for winter.

Concentrations of water-soluble vitamins were in general very low, with no significant differences between leaves and branches. For example, in branches the concentration of riboflavin not detectable, and the concentration in leaves was very low. Pyridoxine was not detectable in leaves but was present in branches. No differences in concentration were observed between male and female plants from Russia. In general, the concentrations of vitamins do no suggest potential use in the economy.

Comparison of metal concentrations in SBT samples from Russia and Germany. SBT leaves from Russia and from Germany had higher metal concentrations than in bark (expected for $\mathrm{Zn}$ and $\mathrm{Cu}$ ). The total phosphorus concentration was much higher in leaves than in bark, which is probably due to fertilisation with phosphorous in the Russian plantation. German samples collected in April and July had much lower concentrations of all metals $-50 \%$ less for $\mathrm{Cu}$ and $\mathrm{Mn}$ to $25 \%$ less for $\mathrm{Fe}$ and $\mathrm{Sr}$.

Polyphenolic compounds. SBT leaves had higher concentrations of polyphenols than in branches, as chlorophyll and other pigments with aromatic structure are included in this analysis. In SBT samples from Germany, it is easy to ex- 
plain the high polyphenol concentration in the July samples and low concentration in April. The bark in July was still fresh and green and of course pigments raised the phenol concentration, and thus harvest time as an effect on the concentrations. Dead wood has low concentration of phenols. The leaves of the Russian SBT varieties had twice greater phenol content than the German samples, while branches from Russia had lower concentration of phenols than bark from German samples, which might be due to harvest time, the SBT variety and of course on the sample material (whole branches versus bark).

In future a detailed characterisation of the phenol components be made to explore potential use of interesting compounds as cosmetics or medicine products.

Summary comparison of SBT samples from Russia and Germany. Dry mass, crude fibre and fat concentrations in German bark samples were lower than the Russian varieties for both female as the male branches. However, starch, carbohydrate and protein concentrations of the German SBT varieties were higher than in Russian SBT branches, which might be due to differences in the growing seasons and climate zones.

\section{CONCLUSION}

The analyses showed interesting differences between the SBT varieties from Russia and Germany, depending on the growing conditions (climate zone, growing season etc.). In Russian samples there were also differences between the female and male plants. The investigation of minor components showed that, for example, vitamin concentrations (vitamin E and water soluble vitamins) were very low and showed no potential use in the economy.

Further research on SBT should continue as this plant contains many biologically actives compounds that can potentially play an important role in nutrition and as dietary supplements.

\section{ACKNOWLEDGEMENTS}

The financial support came from the Federal Ministry for Economic Affairs and Energy on the basis of decision by the
German Bundestag and also from ZIM - Zentrales Innovationsprogramm Mittelstand.

\section{REFERENCES}

Anonymous (1975). DGF Einheitsmethoden. 2. Auflage, einschließlich 22. Akt.Lfg.

Anonymous (2005a). Deutsche Akkreditierungsstelle GmbH. Anlage zur Akkreditierungsurkunde. D-PL-14219-01-00 nach DIN EN ISO/IEC 17025

Anonymous (2005b). Deutsche Akkreditierungsstelle GmbH. Anlage zur Akkreditierungsurkunde. D-PL-17095-01-00 nach DIN EN ISO/IEC 17025 .

Anonymous (2005c). Deutsche Akkreditierungsstelle GmbH. Anlage zur Akkreditierungsurkunde. DPL 17669-01-00 nach DIN EN ISO/IEC 17025 .

Anonymous (2005d). Deutsche Akkreditierungsstelle GmbH. Anlage zur Akkreditierungsurkunde. D-PL-19231-02-00 nach DIN EN ISO/IEC 17025.

Anonymous (2005e). Methodensammlung BVL. Amtlichen Sammlung von Untersuchungsverfahren nach $\S 64$ LFGB, § 35 Vorläufiges Tabakgesetz and $\S 28 \mathrm{~b}$ GenTG

Anonymous (2010). Untersuchung von Lebensmitteln. Bestimmung des Trocken, - massegehaltes in getrockneten Teigwaren. DAkkS, Deutsche Akkreditierungsstelle. ASU L 22.02/04 - 4, 2010-09.

Beveridge, T., Li, T. S. C., Oomah, B. D., Smith, A. (1999). Sea buckthorn products: Manufacture and composition. J. Agric. Food Chem., 47, 3480-3488.

Brad, I., Vlćsceanu, G. A., Brad, I. L., Manea, A. T. (2007). Characterization of sea buckthorn fruits and copses in terms of serotonin and microelements. Innov. Romanian Food Biotechnol., 1, 23-30.

Dwivedi, S. K., Ahmed, Z. (2006). Studies on post harvest management and value addition in seabuckthorn (Hippophea rhamnoides L.). Division of Horticulture and Post Harvest Technology. Field Res. Labor. (India), Leh 194101.

Eidelant, A. S. (2003). Seabuckthorn a unique medicinal and food plant. In: Abstracts of International Seabuckthorn Association Meeting, Berlin, 14-18 September 2003, p. 30.

Maheshwari, D. T., Yogendra Kumar, M. S., Verma, S. K., Singh, V. K., Singh, S. N. (2011). Antioxidant and hepatoprotective activities of phenolic rich fraction of Seabuckthorn (Hippophae rhamnoides L.) leaves. Food Toxicol., 49, 2422-2428.

Mishra, K. P., Mishra, R., Yadav, A. P., Jayashankar, B., Chanda, S., Ganju, L. (2011). A comparative analysis of immunomodulatory potential of Seabuckthorn leaf extract in young and old mice. Biomed. Aging Pathol., Elsevier, 1, 61-64.

Rauscher, K., Engst, R., Freimuth, U., Konrad, H. (1986). Untersuchung von Lebensmitteln. VEB Fachbuchverlag, Leipzig. 982 pp. (see pp. 118-119).

Received 19 September 2016

Accepted in the final form 22 May 2017

\section{SMILTSĒRKŠḲU LAPU, ZARU UN MIZAS ĶĪMISKAIS SASTĀVS}

Pēc smiltsērkšḳu augḷu ražas novākšanas to lapas un zari nonāk atkritumos. Smiltsērkšḳu augli ir slaveni ar savu unikālo kīmisko sastāvu, un, pamatojoties uz to, tiem ir nozīmīga loma uzturā. Autoriem radās ideja, ka smiltsērkšķ lapām, zariem un īpaši mizai arī piemīt unikāls ķīmiskais sastāvs, līdzīgi auģ̣iem. Darba mērḳis bija izpētìt smiltsērkšķu lapu, zaru un mizas ķīmisko sastāvu. Šim nolūkam tika veiktas detalizētas analīzes septiniem smiltsērkšḳu škirṇu paraugiem no Krievijas un četriem no Vācijas. Tika noteikts sausnas, tauku, olbaltumvielu, cietes un kokšḳiedras saturs. Papildus tam tika pētīts kopējais fenolu saturs, metāli, kā arī taukos un ūdenī škīstošie vitamīni. Visas darbā izmantotās analītiskās metodes ir balstītas uz Vācijas oficiālo analīžu metožu krājumu (German ASU - amtliche Sammlung von Untersuchungsverfahren). Pētījuma rezultātā atklājās interesanti aspekti, kā, piemēram, atšķirība starp sievišķajiem un vīrišķajiem augiem. Atškirības tika novērotas arī, salīdzinot Krievijas un Vācijas škirṇu augus. Smiltsērkšku lapas, zari un miza satur vitamīnus, bet ḷoti zemos daudzumos $(<0.1 \%)$. 